\section{ZEW}

Zentrum für Europäische Wirtschaftsforschung GmbH

Centre for European Economic Research

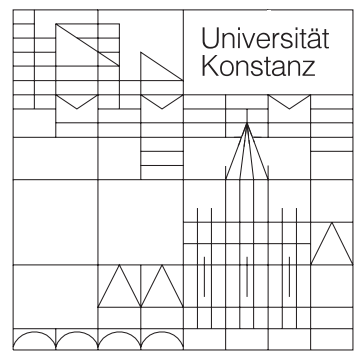

Rechts-, Wirtschafts- und Verwaltungswissenschaftliche Sektion

Fachbereich

Wirtschaftswissenschaften

Diskussionspapiere der DFG-

Forschergruppe (Nr.: 3468269275):

Heterogene Arbeit: Positive und Normative Aspekte der Qualifikationsstruktur der Arbeit

Thomas Zwick, Anja Kuckulenz

Heterogeneous Returns to Training in Personal Services

Mai 2004 
Diskussionspapier der Forschergruppe (Nr.: 3468269275) "Heterogene Arbeit: Positive und Normative Aspekte der Qualifikationsstruktur der Arbeit"

Nr. 04/12, Mai 2004

\section{Heterogeneous Returns to Training in Personal Services}

\section{Thomas Zwick}

Centre for European Economic Research (ZEW)

P.O. Box 103443

D-68034 Mannheim,

Germany

mail: zwick@zew.de

phone: +49-621-1235-283

fax: $\quad+49-621-1235-225$
Anja Kuckulenz

Centre for European Economic Research (ZEW)

P.O. Box 103443

D-68034 Mannheim,

Germany

mail : kuckulenz@zew.de

phone : +49-621-1235-287

fax : $+49-621-1235-225$

\section{Zusammenfassung:}

Using the "Qualification and Career Survey", a rich German data set with information on 0.1 percent of all individuals employed in Germany in 1998/1999, we calculate the earnings effect of training for different "types" of employees in the personal services sector. Interacting training with all explanatory variables in the earnings equation allows us to calculate heterogeneous training returns for employees and firms with different characteristics and to estimate an unbiased average treatment effect. The correction for selection into training by using supply-side changes as external instruments leads to a decrease in the training coefficient in the personal services sector, while the coefficient increases in the entire economy. A further comparison of the results for the personal services sector with those for the entire economy reveals that, on average, employees in personal services gain less from participation in training.

\footnotetext{
JEL Klassifikation : : $331, \mathrm{~J} 24, \mathrm{~J} 31$

Schlüsselwörter : Continuing training, returns to training, endogeneity, employee heterogeneity, training forms, personal services sector

Download/Reference : http://www.wiwi.uni-konstanz.de/forschergruppewiwil
} 


\title{
Heterogeneous Returns to Training in Personal Services
}

\author{
Thomas Zwick and Anja Kuckulenz \\ Centre for European Economic Research (ZEW) \\ P.O. Box 103443 \\ D-68034 Mannheim, Germany
}

\begin{abstract}
Using the "Qualification and Career Survey", a rich German data set with information on 0.1 percent of all individuals employed in Germany in 1998/1999, we calculate the earnings effect of training for different "types" of employees in the personal services sector. Interacting training with all explanatory variables in the earnings equation allows us to calculate heterogeneous training returns for employees and firms with different characteristics and to estimate an unbiased average treatment effect. The correction for selection into training by using supply-side changes as external instruments leads to a decrease in the training coefficient in the personal services sector, while the coefficient increases in the entire economy. A further comparison of the results for the personal services sector with those for the entire economy reveals that, on average, employees in personal services gain less from participation in training.
\end{abstract}

JEL Codes: C31, J24, J31

Key Words: continuing training, returns to training, endogeneity, employee heterogeneity, training forms, personal services sector

* We would like to thank Stephen Bazen, Claudio Lucifora, Friedhelm Pfeiffer, and Wiemer Salverda for helpful comments. Anja Kuckulenz thanks the Deutsche Forschungsgemeinschaft (DFG) for financial support. We also thank Tobias Tönnesmann for his excellent assistance. Neither the Bundesinstitut für berufliche Bildung (BIBB), the Institut für Arbeitsmarkt- und Berufsbildung (IAB), nor the Zentralarchiv (ZA) take any responsibility for the analysis or the interpretation of the data presented here. 


\section{Introduction}

The goal of this paper is to measure the earnings impact of continuing training in the personal services sector in Germany. On the one hand, personal services is one of the sectors with the highest employment growth, on the other hand, in this sector the share of low wage earners is higher than in other sectors. Nevertheless, our knowledge about the specific situation of low wage earners in the services sector is limited (Asplund and Salverda, 2004). An obvious possibility to increase productivity and earnings in low-skilled consumer-related occupations is to increase investments in training for these employees (Hughes, O'Connell and Williams, 2004). Training after entering the labour force constitutes a major part of human capital investments (Heckman, 1999) and continuing training might have a positive impact on the wage level and profile. An important proviso is, however, that training increases earnings for this group of employees. Therefore, we do not only calculate the average training effect on earnings in the personal services sector, but also differentiate between the wage effects for employees with different qualifications and professional status. Heckman (1999) suggests that trainability increases with qualification and tenure and that the effect of training on productivity is larger for higher educated employees. Therefore, it can be assumed that the qualification level and tenure as well as other employee characteristics might have an impact on the earnings effects of training. While some papers on the earnings effects of training account for heterogeneous returns for different educational groups (Lynch, 1992; OECD, 1999), heterogeneity in the returns caused by employer characteristics has not been analysed so far. It can be assumed, however, that some firms are able and willing to pay higher earnings mark-ups to participating employees than others, and we therefore also interact the training returns with employer characteristics. Finally, additional comparisons with the earnings impacts in the entire economy show whether the effects differ between the personal services sector and the rest of the economy and whether the low-skilled fare better or worse in personal services.

It is frequently argued that the group of employees participating in training is different from the other employees with respect to unobservable characteristics (Heckman, 1999; Card, 1999). Employers might tend to offer training only to those individuals who are more trainable, while better motivated individuals may be more likely to pursue off-the-job training (Lynch, 1992). In addition, some firms might be more prone to offer training than others, and therefore some employees might have a higher probability to participate in training, irrespective of their personal characteristics (Zwick, 2004). In this paper, we use supply-side variations to identify training participation. More precisely, we show that employees in firms that recently restructured their production technique or their organisation have a higher probability to participate in training, though it should be noted that restructuring in the firm does not have an (immediate) impact on their wages. This identification strategy has the advantage that it does not capture unobserved employee heterogeneity and hereby avoids biased estimation results (Card, 2000).

This study mainly adds two new aspects to the literature on earnings effects of training. First, we show that the earnings effect of training varies between different "types" of employees and employers, i.e. we discriminate between qualification level, experience, job tenure, economic sector, firm size, and many other attributes. 
Second, we compare the impact of training offered in personal services with the training effects in the entire economy. We correct for the endogeneity of training participation by using instrumental variables. For our analysis, we use a rich and representative German data set with information on all employees.

The paper is structured as follows. In the next section, the theoretical background and econometric methods are briefly discussed. Then, we present the data set and the variables used. This is followed by the empirical evidence, where we first present some descriptive statistics. Second, we estimate the effect of training on the earnings of heterogeneous participants in training in the personal services sector, and third we compare these effects with the training effects in the entire economy. Finally, we conclude with a summary of our results.

\section{Theoretical Background and Econometric Methods}

In order to explain individual earnings, economists traditionally use the so-called Mincer equation, a standard tool in human capital theory (Mincer, 1974; Heckman, Lochner and Todd, 2003). Here, earnings $\ln Y$ are explained by different schooling levels that are captured by vector $S$, experience $\operatorname{Exp}$, experience-squared $E_{x p}{ }^{2}$, and a constant. Experience enters also as a squared term in order to allow earnings to increase with experience with a decreasing rate. In the standard Mincer equation, the growth of earnings during working life, i.e. the experience wage profile, reflects workers' returns to investments in human capital and seniority wages. This means, however, that postschool human capital investments are proxied by work experience or, in other words, are left as a black box. In order to open the black box, we use a dummy for participation in continuing vocational training $T$ in the previous two years as an additional explanatory factor for current earnings. Our data set allows us to capture part of the observable individual heterogeneity left in standard Mincer equations by using a large variety of additional explanatory variables in vector $X$, such as workplace characteristics, firm size, professional career, and personal characteristics of the employee:

$\ln Y=\mu_{0}+\alpha T+\beta_{1}^{\prime} S+\beta_{2} \operatorname{Exp}+\beta_{3} \operatorname{Exp}^{2}+\beta_{4}^{\prime} X+e$.

Training returns may be heterogeneous for different employee groups and depend on employee characteristics and employer characteristics. In order to capture these heterogeneities, we estimate the wage regression, including a full set of interaction terms between the training dummy and all other explanatory variables $\operatorname{Exp}, \operatorname{Exp}^{2}$, and vectors $S$ and $X$. This approach satisfies the suggestion by Card (2000) that the training effects of many subgroups of employees should be compared in order to obtain more reliable estimates on the average treatment effect of training. In addition, the sample averages are subtracted from the interaction terms of training with the explanatory variables. This specification, suggested by Wooldridge (2002), p. 613, reduces unobserved heterogeneity as far as possible and separates the correlation of wages with training from potential correlations of training with other covariates (Bertschek and Spitz, 2003). In addition, it allows us to calculate the average treatment effect of training if we assume that all differences between training 
participants and employees without training during the observation period are captured by the interaction terms with the observables:

$$
\begin{aligned}
& \ln Y=\mu_{0}+\alpha T+\beta_{1}^{\prime} S+\beta_{2} \operatorname{Exp}+\beta_{3} \operatorname{Exp}^{2}+\beta_{4}^{\prime} X+\delta_{1} T(S-\bar{S}) \\
& +\delta_{2} T(\operatorname{Exp}-\overline{\operatorname{Exp}})+\delta_{3} T\left(\operatorname{Exp}^{2}-\overline{\operatorname{Exp}^{2}}\right)+\delta_{4}^{\prime} T(X-\bar{X})+e
\end{aligned}
$$

Employees who participate in training may not be randomly selected, and therefore the ignorability of treatment assumption implied in equations (1) and (2) may be violated. Therefore, the impact of training included as a dummy variable in an OLS earnings equation might be biased because the error term of the earnings equation is correlated with the probability of receiving company training. To consider the effect of an endogenously chosen binary treatment (training), we estimate a treatment effects model that is conditional on two sets of independent variables explaining $\ln Y$ and $T$. The treatment equation measures the unobserved net benefit $T^{*}$ from training. Assuming that firms offer training only if the net benefit is positive, we find:

$$
\begin{aligned}
& T^{*}=\gamma_{0}+\gamma_{1}^{\prime} S+\gamma_{2} \operatorname{Exp}+\gamma_{3} \operatorname{Exp}^{2}+\gamma_{4}^{\prime} X+\gamma_{5}^{\prime} Z+u \\
& T=1, \quad \text { if } T^{*}>0 \\
& T=0, \quad \text { if } T^{*} \leq 0
\end{aligned}
$$

We estimate the binary response model by Probit and include all covariates from our earnings equation.

We use external instruments $Z$ that intuitively explain the training selection process in the establishment and are correlated with training incidence but not with earnings (Griliches and Mairesse, 1998). We adopt the identifying strategy proposed, for example, by Card (2000) and use supply-side sources of variation in training as external instrumental variables. In our case, we include information whether the employer restructured the establishment in the two previous years, i.e. during the period in which training was offered. We use two identifying variables: technical or organisational restructuring. It is well known that firms have to offer more training after restructuring in order to update the skills of their employees in accordance with the new skill demands (Acemoglu and Pischke, 1999; Zwick, 2004). Therefore, participation in training is higher if restructuring has taken place in a firm, irrespective of individual employee characteristics. It can be assumed that some employees participate in training only because the firm restructured recently, and training therefore comes close to a random eligibility variable. As a consequence, our variations in training supply variables satisfy the assumption that the instruments are uncorrelated with other latent employee characteristics that may affect their earnings or, in other words, with unobserved employee heterogeneity (Card, 2000; Wooldridge, 2002).

In the next step, the fitted probabilities of training participation $\hat{T}^{*}$ are calculated from equation (3). According to Wooldridge (2002), the earnings equations (1) and (2) should be estimated by instrumental variables, using a constant, $\hat{T}^{*}, S, \operatorname{Exp}, \operatorname{Exp}^{2}$, 
$X$, and for equation (2) additionally the interactions of $\hat{T}^{*}$ with all demeaned covariates in (4) as instruments as shown between squared brackets:

$$
\begin{aligned}
& T^{* *}= \gamma_{0}+\gamma_{1}^{\prime} S+\gamma_{2} \operatorname{Exp}+\gamma_{3} \operatorname{Exp}^{2}+\gamma_{4}^{\prime} X+\gamma_{5} \hat{T}^{*}\left[+\delta_{1}^{\prime} \hat{T}^{*}(S-\bar{S})\right. \\
&\left.+\delta_{2} \hat{T}^{*}(\operatorname{Exp}-\overline{\operatorname{Exp}})+\delta_{3} \hat{T}^{*}\left(\operatorname{Exp}^{2}-\overline{\operatorname{Exp}^{2}}\right)+\delta_{4}^{\prime} \hat{T}^{*}(X-\bar{X})\right]+u \\
& T=1, \quad \text { if } T^{* *}>0 \\
& T=0, \quad \text { if } T^{* *} \leq 0
\end{aligned}
$$

The IV earnings equation is therefore estimated by (again, the version including the interaction terms is shown between brackets):

$$
\begin{aligned}
\ln Y= & \mu_{0}+\alpha \hat{T}^{* *}+\beta_{1}^{\prime} S+\beta_{2} \operatorname{Exp}+\beta_{3} \operatorname{Exp}^{2}+\beta_{4}^{\prime} X \\
& {\left[+\delta_{1}^{\prime} \hat{T}^{* *}(S-\bar{S})+\delta_{2} \hat{T}^{* *}(\operatorname{Exp}-\overline{\operatorname{Exp}})\right.} \\
& \left.+\delta_{3} \hat{T}^{* *}\left(\operatorname{Exp}^{2}-\overline{\operatorname{Exp}^{2}}\right)+\delta_{4}^{\prime} \hat{T}^{* *}(X-\bar{X})\right]+e,
\end{aligned}
$$

where $\hat{T}^{* *}=\widehat{P}\left(T^{* *}>0\right)$ is the estimated participation in training. The estimated participation in training and the respective interaction terms between training and the covariates are estimated in one step, simultaneously with equation (4). The one-step full-information maximum likelihood estimator (FIML) is based on the entire system of equations (4) and (5) and treats all equations and parameters jointly. With normally distributed disturbances, the estimator is more efficient than the two stage least squares (2SLS) estimator.

\section{The Data}

In order to analyse the impact of training on earnings empirically, we use a rich data set, compiled from a representative sample of 0.1 percent of all individuals employed in Germany. The BIBB/IAB "Qualification and Career survey" is implemented every seven years, but it is not a panel. We use the latest wave available, which is from the survey in 1998/99. It comprises more than 34,000 employees. The crosssection data on employed individuals in Germany contain detailed information on the qualification and the professional career of each individual, the organisational and technological environment of jobs, and the qualificational requirements. Furthermore, information about the employer and some personal attributes are included. This cross-section data doesn't allow us to control for unobserved heterogeneity by taking individual-specific fixed effects. This proviso is to some extent outweighed, however, by the fact that the data set contains an exceptionally extensive set of explanatory variables that are potentially correlated with training

1 "Qualification and Career Survey" of the German Federal Institute for Vocational Training (BIBB) and the Federal Employment Service (IAB). 
participation and wages. Specifically, we use the following variables (see also table A1 in the appendix for the complete list with detailed descriptions):

- The endogenous variable is log midpoints of earnings in 1998/1999 from 18 categories. $^{2}$ This variable has the advantage that earnings of highly paid workers are not censored from above.

- The key explanatory variable is participation in training during the years 19961998. Training comprises participation in courses or seminars, fairs, lectures, onthe-job training, specific company training, or taking over special tasks and reading technical literature, as well as internships or any other kind of continuing training. The training dummy might stand for quite substantial amounts of training, because the employees might participate in various courses and more than once in the same category of training during 48 months. In addition, only formal training courses that lead to professional qualifications are included in the data set - short and informal training spells are explicitly excluded. On average, employees obtained about one week of training per year in 1996-1998 (Institut der deutschen Wirtschaft, 2002).

- The external identifying variables for training participation originate from questions on the changes in the workplace during the period in which training took place (1996-1998). We use two variables: technical restructuring (introduction of new production techniques, machines, production materials or computer programmes) and organisational restructuring (re-organisation of departments or work groups).

- Further explanatory variables for earnings are those found in the Mincer equation, i.e. actual work experience, job tenure, and dummies for the highest educational achievement. These variables are related to the situation in 1998/1999.

- In addition, we use the following current job characteristics: computer use, profitsharing, incentive wages, overtime work, and whether a job is temporary. Also previous unemployment spells are controlled for. These variables allow us to control a large part of the individual heterogeneity between the employees.

- Finally, we also add seven dummies for the firm size and a dummy for the location of the firm in East or West-Germany. A further employer characteristic used is whether the firm is in a good economic situation in 1998/1999.

2 The first category includes all earnings below $€ 307$, the second includes earnings from $€ 307$ until $€ 511$. The following categories comprise earnings intervals of $€$ 256 up to $€ 3,068$. From $€ 3,068$ to earnings of $€ 5,113$, the intervals are in steps of $€$ 511. The next category comprises earnings from $€ 5,113$ until $€ 7,669$ and the last category includes all earnings of $€ 7,669$ and above. The unbounded upper range is coded as $€ 8,947$. 
We included the following sectors in our sample for personal services: retail trade, laundry, hairdresser, chain store company, kiosk and gas filling station, mail-orderhouse, passenger traffic and travel agency, hotel and restaurant, hospital, nursing home and sanatorium, medical practice, law practice, architectural practice, engineering practice and tax advisor, recreational sector, sports and fitness and other trading and services (also compare Hughes, O’Connell and Williams, 2004).

Only full-time employees, i.e. those employees working 30 hours and above per week, are included in the sample. The analysis is restricted to male employees, because the data do not allow us to model participation in the labour market simultaneously, which would be important for examining earnings effects for women ${ }^{3}$. This reduces the sample for the entire economy to around 14,800 individuals, and around 2,300 of those were employed in personal services.

\section{Results}

\section{Descriptive Statistics}

One of the motivations to concentrate on the personal services sector is the finding that this sector employs a relatively high share of low-wage employees (Hughes, O'Connell and Williams, 2004). Graph 1 shows indeed that the share of employees with incomes below about $€ 2000$ per month is higher in this sector than in the entire economy, and average earnings in the personal services sector is $€ 2272$, while it is $€$ 2346 in the entire economy. Note that these differences cannot be completely explained by differences in the qualification structure because it is rather similar. A part of the differences is probably explained by the lower average tenure and work experience in the personal services sector, however (compare table A1 in the appendix).

\section{$>$ graph1 about here $<<$}

If we compare the training incidence between personal services and the German economy, we find that training incidence is slightly higher in personal services. It is interesting to note that especially the training incidence of less qualified employees is higher in the personal services sector than in the entire economy (compare table 1). This suggests that the higher incidence of low-wage earners in the restricted sample is not a consequence of a lower training participation of less qualified employees.

\section{Earnings Impact of Training}

We calculate equation (1), i.e. the extended Mincer earnings equation including the training dummy and a broad variety of employer and employee characteristics but not the interaction terms between training and the other explanatory variables by

${ }^{3}$ In order to include women, we would need to correct for sample selection in the earnings equation. This is impossible since only those women who participate in the labour market are included in the data. 
$\mathrm{OLS}^{4}$. Here, the training coefficient is 0.12 and significant in the personal services sector (compare column 2 in table 2). This is larger than the training coefficient in the entire economy (compare column 2 in table 3 ). If we allow for heterogeneity in the returns of training by adding the interaction terms according to equation (2), the average treatment effect increases for our restricted sample and for the entire economy (see columns 4 of tables 2 and 3). This effect is familiar from previous studies (Kuckulenz and Zwick, 2003). In addition, we find that the earnings effect of training is higher for employees with higher schooling levels and larger firms. The OECD (1999, p.165) also finds for Germany a positive (albeit insignificant) interaction between the earnings effect of training and education. For France, Italy, the Netherlands, and Great Britain the OECD reports larger wage gains for employees with lower education, however. We learn from a comparison between the personal services sector and the entire economy that the additional earnings effect of trained employees with higher tenure is lower in the personal services sector. Moreover, also the earnings mark-up of trained employees with temporary contracts and overtime work is lower there. On the other hand, also in the entire economy, lower educated employees earn a lower earnings mark-up if they train. Most other interaction effects between the covariates and the earnings impact of training are insignificant.

Before we can draw firm conclusions from our analysis, we have to take the selection issue into account, however. In a first step, training participation is explained by technical and organisational restructuring and the explanatory variables from the earnings equation according to equation (3). Table A2 in the appendix shows that employees in firms that recently restructured have a higher probability to participate in training. It is interesting to note that in personal services work experience and tenure do not have an impact on training incidence, whereas in the entire economy training incidence increases with higher work experience and tenure. In both samples, the higher qualified employees have a comparatively higher probability of participating in training. This is frequently found in the literature (OECD, 1999; Booth, Francesconi and Zoega, 2003; Zwick, 2004). In addition, training is also offered more frequently to employees with overtime work and incentive payments.

The earnings impact of training strongly changes if training is estimated by IV, using the predicted training values and the list of explanatory variables according to equation (4). The estimated earnings effect of training turns insignificant in the personal services sector if equation (5) is estimated without the interaction terms within the squared brackets, see column 6 of table 2. For the entire German economy, the IV estimates increase, however, and stay significant, see column 6 of table 3 (also compare Kuckulenz and Zwick, 2003). This indicates that in the personal services sector mainly employees with unobserved higher wage earnings abilities have a higher chance to obtain training while this is not the case in all sectors of the economy on average. Unobserved firm characteristics are likely to have an important impact as well. Specifically, those personal services firms that

${ }^{4}$ The estimation results are very similar, if we estimate the earnings equation by interval regression techniques taking into account that the dependent variable is coded in intervals (Kuckulenz and Zwick, 2003). 
offer training are likely to pay more to their employees also without training. In other words, the higher earnings of training participants are not a causal effect of training but they are due to the selection of employees and firms with unobserved characteristics that are positively correlated with earnings. The positive selection effect in the personal services sector is even stronger than the correction of measurement errors that induce a downward bias on the training coefficient in the OLS estimation (Griliches and Hausman, 1986). Apart from the differences in earnings effects of training, the impact of the other explanatory variables is similar in both samples: earnings increase with experience, tenure, and professional and school education. Larger firms and firms in a good economic situation pay more. Employees with profit sharing or incentive wages and computer users earn more. Employees with temporary contracts as well as employees with previous unemployment spells earn less. These results are familiar from the literature (Lynch, 1992; OECD, 1999; Goux and Maurin, 2000; Pischke, 2001; Booth, Francesconi and Zoega, 2003; Kuckulenz and Zwick, 2003).

We also calculated the IV estimates of the earnings equation including the interaction terms between training and the other covariates. Probably due to the small sample size and the large number of instruments, most coefficients were badly determined, however, and therefore we do not report the estimation results here.

\section{Conclusions}

The main result of this paper is that training does not lead to an earnings increase in the personal services sector. In contrast, training participation in 1996-1998 leads to a significant earnings increase for employees in the entire German economy in 1998/1999. In the personal services sector, the share of employees in the low wage category is higher than in the rest of the economy. These employees therefore cannot improve their financial situation by training, although the firms train a fair share of them. This result is additionally aggravated by the fact that the earnings impact of training is higher for higher qualified employees. This means for the entire German economy that training exacerbates earnings differences in those sectors with positive training returns because mainly higher educated employees participate in the rents generated by training.

We take endogeneity of training into account by instrumenting the training dummy by exogenous training supply changes. For the entire German economy, the IV regression leads to a higher estimation of the training impact of earnings, while for the personal services sector the coefficient is significantly lower and turns insignificant. We conclude that in the personal services sector those employees obtain training who have unobserved personal characteristics that increase their ability to earn more or who work in firms with unobserved characteristics that induce them to pay higher wages.

\section{Literature}

Acemoglu, D. / J.-S. Pischke (1999): Beyond Becker: Training in Imperfect Labor Markets, The Economic Journal, 109, 112 - 142. 
Asplund, R. / W. Salverda (2004): Company Training and Services with a Focus on Low Skills, International Journal of Manpower, 25, forthcoming.

Bertschek, I. / A. Spitz (2003): IT, Organizational Change and Wages, ZEW Discussion Paper No. 03-69, Mannheim.

Booth, A. L. / M. Francesconi / G. Zoega (2003): Unions, Work-Related Training, and Wages: Evidence for British Men, IZA Discussion Paper No. 737, Bonn.

Card, D. (1999): The Causal Effect of Education on Earnings, in: Ashenfelter, O. and D. Card (eds.): Handbook of Labour Economics, vol. 3A, chap. 30, Elsevier, Amsterdam, 1801-1863.

Card, D. (2000): Estimating the Return to Schooling: Progress on Some Persistent Econometric Problems, NBER Working Paper No. 7769, Cambridge, MA.

Goux, D. / E. Maurin (2000): Returns to Firm Provided Training: Evidence from French Worker-Firm Matched Data, Labor Economics, 7, 1-19.

Griliches, Z. / J. Hausman (1986): Errors in Variables in Panel Data, Journal of Econometrics, 31, 93-118.

Griliches, Z. / J. Mairesse (1998): Production Functions: The Search for Identification, in: Strøm, S. (ed.): Econometrics and Economic Theory in the $20^{\text {th }}$ Century, Cambridge University Press, Cambridge.

Heckman, J. (1999): Policies to Foster Human Capital, NBER Working Paper No. 7288, Cambridge, MA.

Heckman, J. / L. Lochner / P. Todd (2003): Fifty Years of Mincer Earnings Regressions, IZA Discussion Paper No. 775, Bonn.

Hughes, G. / P. O’Connell / J. Williams (2004): Company Training and Low-Skill Consumer-Service Jobs in Ireland, International Journal of Manpower, 25, forthcoming.

Institut der deutschen Wirtschaft (2002): Deutschland in Zahlen, Köln.

Kuckulenz, A. / T. Zwick (2003): The Impact of Training on Earnings - Differences Between Participant Groups and Training Forms, ZEW Discussion Paper No. 03-57, Mannheim. 
Lynch, L. M. (1992): Private-Sector Training and the Earnings of Young Workers, The American Economic Review, 82 (1), 299-321.

Mincer, J. (1974): Schooling, Experience and Earnings, National Bureau of Economic Research, New York.

OECD (1999): Employment Outlook, Paris.

Pischke, J.-S. (2001): Continuous Training in Germany, Journal of Population Economics, 14, 523-548.

Wooldridge, J. M. (2002): Econometric Analysis of Cross Section and Panel Data, MIT Press, Cambridge, Mass.

Zwick, T. (2004): Training - A Strategic Enterprise Decision?, in: G. Fandel / U. Backes-Gellner / M. Schlüter / J. Staufenbiel (eds.): Modern Concepts of the Theory of the Firm - Managing Enterprises of the New Economy, Springer, Heidelberg, 355-366. 

Table 1: Training participation

\begin{tabular}{lcc}
\hline Employee Groups & $\begin{array}{c}\text { Personal } \\
\text { Services } \\
\text { Sectors }\end{array}$ & All Sectors \\
\hline All & 0.69 & 0.66 \\
Without School Leaving Certificate & 0.29 & 0.25 \\
Lower Secondary School & 0.54 & 0.51 \\
Intermediate Secondary School & 0.72 & 0.70 \\
Entrance Examination for University of Applied & 0.81 & 0.88 \\
Sciences & & \\
High School Diploma & 0.83 & 0.86
\end{tabular}

Source: BIBB-IAB 1998/99, own calculations.

Graph 1: Earnings shares in the personal services sector and the entire economy

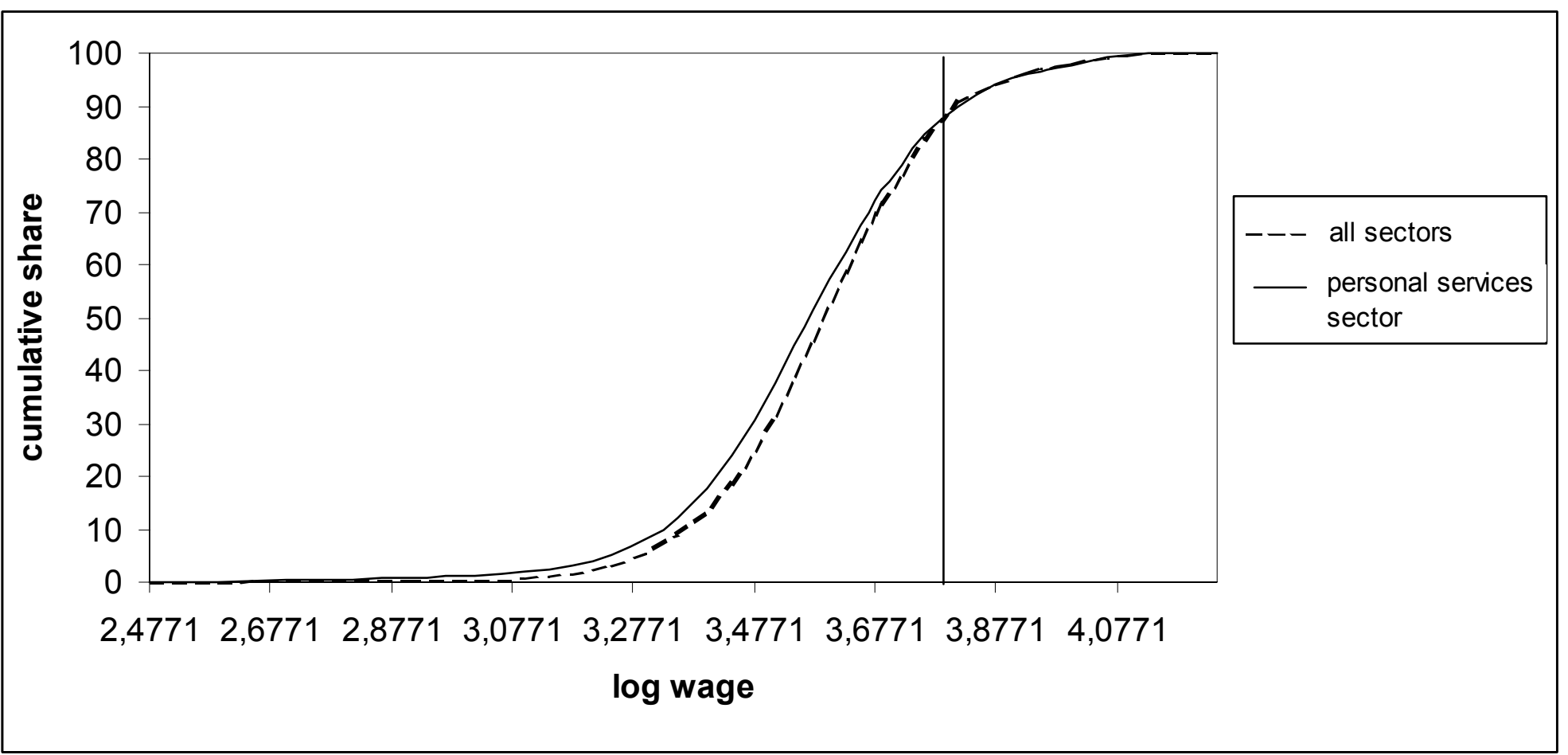

Remark: Wages calculated in DM $(1 \mathrm{DM}=0.511 €)$. 
Table 2: Extended Mincer equations, personal services sector, endogenous variable: log earnings

\begin{tabular}{|c|c|c|c|c|c|c|}
\hline & \multicolumn{2}{|c|}{ OLS } & \multicolumn{2}{|c|}{ OLS with interaction terms } & \multicolumn{2}{|c|}{ IV } \\
\hline $\begin{array}{l}\text { Exogenous } \\
\text { Variables }\end{array}$ & Coefficients & t-Values & Coefficients & t-Values & Coefficients & t-Values \\
\hline Training & 0.12 & 6.52 & 0.14 & 6.43 & 0.01 & 0.08 \\
\hline $\begin{array}{l}\text { Professional } \\
\text { Experience }\end{array}$ & 0.02 & 5.54 & 0.01 & 2.72 & 0.02 & 5.53 \\
\hline $\begin{array}{l}\text { Professional } \\
\text { Experience }^{2}\end{array}$ & 0.00 & -3.69 & 0.00 & -2.05 & 0.00 & -3.72 \\
\hline Company Tenure & 0.01 & 3.42 & 0.01 & 2.40 & 0.01 & 3.40 \\
\hline Company Tenure ${ }^{2}$ & 0.00 & -1.54 & 0.00 & -0.96 & 0.00 & -1.53 \\
\hline Firmsize 1-4 & -0.10 & -2.8 & -0.14 & -2.33 & -0.10 & -2.81 \\
\hline Firmsize 5-9 & -0.06 & -2.48 & -0.06 & -1.53 & -0.06 & -2.46 \\
\hline Firmsize 50-99 & 0.05 & 2.15 & -0.02 & -0.48 & 0.06 & 2.16 \\
\hline Firmsize 100-499 & 0.10 & 4.23 & 0.04 & 0.95 & 0.10 & 4.16 \\
\hline Firmsize 500-999 & 0.09 & 2.44 & 0.09 & 1.31 & 0.10 & 2.46 \\
\hline Firmsize $1000+$ & 0.11 & 4.42 & 0.02 & 0.37 & 0.11 & 4.09 \\
\hline $\begin{array}{l}\text { Lower Secondary } \\
\text { School }\end{array}$ & -0.05 & -2.43 & -0.05 & -1.51 & -0.06 & -2.41 \\
\hline $\begin{array}{l}\text { Entrance Exam for } \\
\text { University of } \\
\text { Applied Sciences }\end{array}$ & 0.13 & 3.74 & -0.02 & -0.31 & 0.13 & 3.7 \\
\hline $\begin{array}{l}\text { High School } \\
\text { Diploma }\end{array}$ & 0.15 & 5.21 & 0.06 & 0.90 & 0.16 & 5.19 \\
\hline $\begin{array}{l}\text { Without School } \\
\text { Leaving Certificate }\end{array}$ & -0.22 & -2.35 & -0.17 & -1.74 & -0.23 & -2.5 \\
\hline $\begin{array}{l}\text { Without } \\
\text { Professional } \\
\text { Degree }\end{array}$ & -0.14 & -2.68 & -0.18 & -1.49 & -0.17 & -2.59 \\
\hline $\begin{array}{l}\text { Dual } \\
\text { Apprenticeship }\end{array}$ & -0.04 & -0.89 & -0.03 & -0.24 & -0.04 & -0.93 \\
\hline Master Craftsman & 0.04 & 0.78 & -0.01 & -0.11 & 0.05 & 0.95 \\
\hline $\begin{array}{l}\text { University of } \\
\text { Applied Sciences }\end{array}$ & 0.02 & 0.42 & -0.02 & -0.13 & 0.03 & 0.5 \\
\hline University & 0.26 & 4.65 & 0.15 & 0.98 & 0.26 & 4.66 \\
\hline Unemployment & -0.01 & -0.73 & 0.00 & 0.03 & -0.01 & -0.73 \\
\hline Computer & 0.12 & 6.44 & 0.14 & 3.99 & 0.14 & 4.08 \\
\hline Temporary Work & -0.11 & -3.44 & -0.12 & -1.97 & -0.12 & -3.38 \\
\hline $\begin{array}{l}\text { Good Economic } \\
\text { Situation }\end{array}$ & 0.05 & 3.05 & 0.03 & 0.85 & 0.04 & 2.37 \\
\hline Overtime Work & 0.12 & 5.87 & 0.09 & 2.80 & 0.13 & 4.96 \\
\hline Profit-Sharing & 0.15 & 5.35 & 0.14 & 2.08 & 0.16 & 5.2 \\
\hline Incentive Wage & 0.04 & 1.89 & 0.00 & 0.04 & 0.05 & 2.02 \\
\hline East & -0.31 & -14.15 & -0.31 & -7.32 & -0.30 & -12.82 \\
\hline $\begin{array}{l}\text { Constant } \\
\text { Interaction Terms }\end{array}$ & 7.74 & 122.84 & 7.84 & 52.94 & 7.80 & 76.85 \\
\hline $\begin{array}{l}\text { Professional } \\
\text { Experience }\end{array}$ & & & 0.00 & 0.55 & & \\
\hline $\begin{array}{l}\text { Professional } \\
\text { Experience }^{2}\end{array}$ & & & 0.00 & -0.17 & & \\
\hline Company Tenure & & & 0.00 & -0.49 & & \\
\hline Company Tenure ${ }^{2}$ & & & 0.00 & -0.04 & & \\
\hline Firmsize 1-4 & & & 0.07 & 0.95 & & \\
\hline Firmsize 5-9 & & & -0.01 & -0.16 & & \\
\hline
\end{tabular}


Firmsize 50-99

$\begin{array}{ll}0.11 & 1.88\end{array}$

Firmsize 100-499

0.07

1.45

Firmsize 500-999

$0.00 \quad-0.01$

Firmsize 1000+

$0.14 \quad 2.43$

Lower Secondary

$-0.01$

$-0.20$

School

Entrance Exam for

$0.19 \quad 2.16$

University of

Applied Sciences

High School

$\begin{array}{ll}0.12 & 1.57\end{array}$

Diploma

Without School

$-0.17 \quad-0.73$

Leaving Certificate

Without

$\begin{array}{ll}0.08 & 0.58\end{array}$

Professional

Degree

Dual

$-0.02$

$-0.15$

Apprenticeship

Master Craftsman

$\begin{array}{ll}0.06 & 0.46\end{array}$

University of

$\begin{array}{ll}0.05 & 0.27\end{array}$

Applied Sciences

University

$0.11 \quad 0.66$

Unemployment

$-0.02$

$-0.59$

Computer

$-0.04 \quad-0.93$

Temporary Work

$0.00 \quad 0.06$

Good Economic

$0.03 \quad 0.88$

Situation

Overtime Work

$\begin{array}{ll}0.06 & 1.47\end{array}$

Profit-Sharing

$0.02 \quad 0.22$

Incentive Wage

$0.05 \quad 1.02$

East

$-0.01$

$-0.22$

$\begin{array}{lll}\mathrm{N} & 1983 & 1983\end{array}$

0.48

\begin{tabular}{ll}
$\mathrm{R}^{2}$ & 0.47 \\
\hline Source: BIBB-IAB 1998/99, own calculations.
\end{tabular} 
Table 3: Extended Mincer equations, all sectors, endogenous variable: log earnings

\begin{tabular}{|c|c|c|c|c|c|c|}
\hline & \multicolumn{2}{|c|}{ OLS } & \multicolumn{2}{|c|}{ OLS with interaction terms } & \multicolumn{2}{|c|}{ IV } \\
\hline $\begin{array}{l}\text { Exogenous } \\
\text { Variables }\end{array}$ & Coefficients & t-Values & Coefficients & $\mathrm{t}$-Values & Coefficients & t-Values \\
\hline Training & 0.09 & 12.98 & 0.11 & 13.53 & 0.15 & 3.42 \\
\hline $\begin{array}{l}\text { Professional } \\
\text { Experience }\end{array}$ & 0.02 & 14.7 & 0.01 & 6.97 & 0.02 & 14.2 \\
\hline $\begin{array}{l}\text { Professional } \\
\text { Experience }^{2}\end{array}$ & 0.00 & -10.62 & 0.00 & -6.21 & 0.00 & -9.94 \\
\hline Company Tenure & 0.01 & 6.74 & 0.01 & 6.09 & 0.01 & 6.5 \\
\hline Company Tenure ${ }^{2}$ & 0.00 & -2.62 & 0.00 & -2.55 & 0.00 & -2.61 \\
\hline Firmsize 1-4 & -0.05 & -3.23 & -0.09 & -3.04 & -0.06 & -3.29 \\
\hline Firmsize 5-9 & -0.06 & -5.34 & -0.08 & -4.75 & -0.06 & -5.38 \\
\hline Firmsize 50-99 & 0.04 & 3.75 & 0.01 & 0.82 & 0.03 & 3.72 \\
\hline Firmsize 100-499 & 0.07 & 8.62 & 0.05 & 3.54 & 0.07 & 8.48 \\
\hline Firmsize 500-999 & 0.08 & 6.99 & 0.07 & 3.17 & 0.08 & 6.68 \\
\hline Firmsize $1000+$ & 0.11 & 11.87 & 0.09 & 5.35 & 0.11 & 11.77 \\
\hline $\begin{array}{l}\text { Lower Secondary } \\
\text { School }\end{array}$ & -0.05 & -6.36 & -0.01 & -0.74 & -0.04 & -4.98 \\
\hline $\begin{array}{l}\text { Entrance Exam for } \\
\text { University of } \\
\text { Applied Sciences }\end{array}$ & 0.12 & 9.57 & 0.07 & 1.85 & 0.12 & 9.22 \\
\hline $\begin{array}{l}\text { High School } \\
\text { Diploma }\end{array}$ & 0.13 & 11.29 & 0.10 & 3.48 & 0.13 & 11.14 \\
\hline $\begin{array}{l}\text { Without School } \\
\text { Leaving Certificate }\end{array}$ & -0.04 & -1.36 & 0.00 & 0.08 & -0.03 & -0.98 \\
\hline $\begin{array}{l}\text { Without } \\
\text { Professional } \\
\text { Degree }\end{array}$ & -0.10 & -4.34 & -0.12 & -3.17 & -0.09 & -3.95 \\
\hline $\begin{array}{l}\text { Dual } \\
\text { Apprenticeship }\end{array}$ & -0.01 & -0.47 & 0.00 & -0.1 & -0.01 & -0.59 \\
\hline Master Craftsman & 0.10 & 4.69 & 0.07 & 1.68 & 0.09 & 4.01 \\
\hline $\begin{array}{l}\text { University of } \\
\text { Applied Sciences }\end{array}$ & 0.13 & 5.36 & 0.13 & 2.42 & 0.12 & 4.87 \\
\hline University & 0.28 & 11.97 & 0.25 & 4.7 & 0.27 & 11.11 \\
\hline Unemployment & -0.04 & -5.61 & -0.03 & -2.53 & -0.04 & -5.71 \\
\hline Computer & 0.11 & 15.41 & 0.08 & 6.13 & 0.09 & 7.24 \\
\hline Temporary Work & -0.09 & -5.95 & -0.06 & -2.58 & -0.09 & -5.77 \\
\hline $\begin{array}{l}\text { Good Economic } \\
\text { Situation }\end{array}$ & 0.07 & 11.14 & 0.05 & 4.82 & 0.07 & 11.05 \\
\hline Overtime Work & 0.08 & 11.32 & 0.07 & 6.27 & 0.08 & 9.53 \\
\hline Profit-Sharing & 0.12 & 9.44 & 0.05 & 2.07 & 0.12 & 9.27 \\
\hline Incentive Wage & 0.03 & 4.74 & 0.05 & 3.79 & 0.03 & 3.97 \\
\hline East & -0.30 & -36.15 & -0.29 & -17.63 & -0.31 & -35 \\
\hline $\begin{array}{l}\text { Constant } \\
\text { Interaction Terms }\end{array}$ & 7.81 & 302.23 & 7.85 & 173.96 & 7.79 & 251.51 \\
\hline $\begin{array}{l}\text { Professional } \\
\text { Experience }\end{array}$ & & & 0.00 & 1.91 & & \\
\hline $\begin{array}{l}\text { Professional } \\
\text { Experience }^{2}\end{array}$ & & & 0.00 & -0.22 & & \\
\hline Company Tenure & & & -0.01 & -2.8 & & \\
\hline Company Tenure ${ }^{2}$ & & & 0.00 & 1.35 & & \\
\hline Firmsize 1-4 & & & 0.05 & 1.36 & & \\
\hline Firmsize 5-9 & & & 0.03 & 1.59 & & \\
\hline
\end{tabular}


Firmsize 50-99

Firmsize 100-499

Firmsize 500-999

Firmsize $1000+$

Lower Secondary

School

Entrance Exam for

University of

Applied Sciences

High School

Diploma

Without School

Leaving Certificate

Without

Professional

Degree

Dual

Apprenticeship

Master Craftsman

University of

Applied Sciences

University

Unemployment

Computer

Temporary Work

Good Economic

Situation

Overtime Work

Profit-Sharing

Incentive Wage

East Germany

$\mathrm{N}$

\begin{tabular}{lr}
$\mathrm{R}^{2}$ & 12557 \\
\hline
\end{tabular}

Source: BIBB-IAB 1998/99, own calculations.

$\begin{array}{cc}0.04 & 1.77 \\ 0.03 & 1.61 \\ 0.02 & 0.69 \\ 0.03 & 1.33 \\ -0.06 & -4.23 \\ 0.06 & 1.53\end{array}$

$\begin{array}{ll}0.05 & 1.53\end{array}$

$-0.12 \quad-1.45$

$\begin{array}{ll}0.03 & 0.59\end{array}$

$\begin{array}{ll}-0.02 & -0.41\end{array}$

$\begin{array}{ll}0.02 & 0.53\end{array}$

$\begin{array}{ll}-0.02 & -0.39\end{array}$

$\begin{array}{ll}0.02 & 0.31\end{array}$

$-0.01 \quad-0.83$

$\begin{array}{ll}0.04 & 2.57\end{array}$

$-0.04 \quad-1.37$

$\begin{array}{ll}0.02 & 1.99\end{array}$

$0.02 \quad 1.02$

$0.08 \quad 2.88$

$\begin{array}{ll}-0.02 & -1.41\end{array}$

$-0.03 \quad-1.43$

$12557 \quad 12557$

0.47

0.46 


\section{Appendix}

Table A1: Descriptive statistics - average values and shares

\begin{tabular}{|c|c|c|}
\hline Variables & $\begin{array}{c}\text { Personal Services } \\
\text { Sector }\end{array}$ & All Sectors \\
\hline Earnings (in $€$ ) & 2272 & 2346 \\
\hline Professional Experience & 20.63 & 22.30 \\
\hline Company Tenure & 9.73 & 12.77 \\
\hline Firmsize 1-4 & 0.09 & 0.05 \\
\hline Firmsize 5-9 & 0.13 & 0.09 \\
\hline Firmsize 50-99 & 0.12 & 0.13 \\
\hline Firmsize 100-499 & 0.16 & 0.21 \\
\hline Firmsize 500-999 & 0.06 & 0.07 \\
\hline Firmsize 1000 and above & 0.11 & 0.14 \\
\hline Lower Secondary School & 0.37 & 0.43 \\
\hline Intermediate Secondary School & 0.33 & 0.32 \\
\hline Entrance Examination for & 0.08 & 0.08 \\
\hline \multicolumn{3}{|l|}{ University of Applied Sciences } \\
\hline High School Diploma & 0.21 & 0.17 \\
\hline Without School Leaving Certificate & 0.01 & 0.01 \\
\hline Without Professional Degree & 0.11 & 0.10 \\
\hline Full-Time Vocational School & 0.03 & 0.02 \\
\hline Degree from Dual Apprenticeship & 0.59 & 0.59 \\
\hline \multicolumn{3}{|l|}{ System } \\
\hline Master Craftsman & 0.09 & 0.12 \\
\hline University of Applied Sciences & 0.07 & 0.07 \\
\hline University & 0.11 & 0.10 \\
\hline Previously unemployed & 0.34 & 0.30 \\
\hline Computer at work & 0.54 & 0.50 \\
\hline Temporary Work & 0.09 & 0.06 \\
\hline $\begin{array}{l}\text { Good economic situation of } \\
\text { employer }\end{array}$ & 0.52 & 0.56 \\
\hline Overtime Work & 0.81 & 0.81 \\
\hline Profit-Sharing & 0.11 & 0.08 \\
\hline Incentive Wage & 0.17 & 0.22 \\
\hline
\end{tabular}

Source: BIBB-IAB 1998/99, own calculations. 
Table A2: Explanation of training incidence, Probit model, endogeneous variable: training dummy

\begin{tabular}{|c|c|c|c|c|}
\hline \multirow[t]{2}{*}{ Explanatory Variables } & \multicolumn{2}{|c|}{ Personal Services Sector } & \multicolumn{2}{|c|}{ Entire Economy } \\
\hline & coefficient & t-value & coefficient & t-value \\
\hline Technical & 0.23 & 2.83 & 0.35 & 11.24 \\
\hline \multicolumn{5}{|l|}{ Restructuring } \\
\hline Organisational & 0.36 & 3.57 & 0.25 & 6.42 \\
\hline \multicolumn{5}{|l|}{ Restructuring } \\
\hline Professional & 0.01 & 0.92 & 0.02 & 3.78 \\
\hline \multicolumn{5}{|l|}{ Experience } \\
\hline Professional & 0.00 & -1.11 & 0.00 & -4.86 \\
\hline \multicolumn{5}{|l|}{ Experience $^{2}$} \\
\hline Company Tenure & 0.00 & 0.28 & 0.01 & 2.11 \\
\hline Company Tenure ${ }^{2}$ & 0.00 & -0.13 & 0.00 & -0.45 \\
\hline Firmsize 1-4 & -0.04 & -0.34 & 0.05 & 0.91 \\
\hline Firmsize 5-9 & 0.06 & 0.61 & 0.06 & 1.38 \\
\hline Firmsize 50-99 & -0.02 & -0.20 & 0.00 & -0.07 \\
\hline Firmsize 100-499 & 0.11 & 1.16 & 0.00 & -0.13 \\
\hline Firmsize 500-999 & 0.23 & 1.70 & 0.12 & 2.28 \\
\hline $\begin{array}{l}\text { Firmsize } 1000 \text { and } \\
\text { above }\end{array}$ & -0.20 & -1.76 & -0.01 & -0.14 \\
\hline Lower Secondary School & -0.21 & -2.74 & -0.22 & -7.14 \\
\hline Entrance Exam for & 0.11 & 0.86 & 0.25 & 4.21 \\
\hline \multicolumn{5}{|l|}{$\begin{array}{l}\text { University of Applied } \\
\text { Sciences }\end{array}$} \\
\hline High School Diploma & 0.02 & 0.14 & 0.12 & 2.35 \\
\hline $\begin{array}{l}\text { Without School Leaving } \\
\text { Certificate }\end{array}$ & -0.36 & -1.13 & -0.39 & -3.04 \\
\hline $\begin{array}{l}\text { Without Professional } \\
\text { Degree }\end{array}$ & -0.67 & -3.32 & -0.33 & -3.94 \\
\hline Dual Apprenticeship & -0.14 & -0.76 & 0.07 & 0.87 \\
\hline Master Craftsman & 0.40 & 1.87 & 0.50 & 5.91 \\
\hline $\begin{array}{l}\text { University of Applied } \\
\text { Sciences }\end{array}$ & 0.21 & 0.93 & 0.48 & 5.07 \\
\hline University & 0.45 & 2.07 & 0.61 & 6.42 \\
\hline Unemployment & -0.02 & -0.25 & 0.01 & 0.21 \\
\hline Computer & 0.52 & 7.41 & 0.63 & 22.70 \\
\hline Temporary Work & -0.19 & -1.71 & -0.09 & -1.74 \\
\hline Good Economic Situation & -0.15 & -2.34 & -0.11 & -4.26 \\
\hline Overtime Work & 0.35 & 4.76 & 0.24 & 8.22 \\
\hline Profit-Sharing & 0.21 & 1.92 & 0.08 & 1.62 \\
\hline Incentive Wage & 0.21 & 2.43 & 0.15 & 4.84 \\
\hline East Germany & 0.20 & 2.26 & 0.18 & 5.21 \\
\hline Constant & -0.06 & -0.27 & -0.45 & -4.72 \\
\hline $\mathrm{N}$ & 2289 & & 14521 & \\
\hline Pseudo $\mathrm{R}^{2}$ & 0.18 & & 0.19 & \\
\hline
\end{tabular}

Source: BIBB-IAB 1998/99, own calculations. 